\title{
SACRED PLACES AND CULTURAL MEMORY ON A TRIPLE BORDER \\ REVITALIZING VENERATION OF THE HERMIT SAINTS AT OSOGOVO MONASTERY
}

\author{
PETKO HRISTOV
}

This article presents the results of fieldwork at Osogovo Monastery, that took place during the major Christian Orthodox holiday the Dormition of the Mother of God (Mac. Golema Bogorodica), as well as on the day of the patron saint of the monastery, St. Joachim of Osogovo. The article observes and analyzes contemporary rituals and pilgrimage practices related to local religious beliefs and cultural memory in the border area between Bulgaria, North Macedonia, and Serbia, as well as the existence of transborder religious tourism.

Keywords: local religion, border, identity, cultural memory, pilgrimage, religious tourism
$V$ razpravi so predstavljeni rezultati terenskega dela $v$ samostanu Osogovo (Severna Makedonija) ob velikem krščanskem pravoslavnem prazniku Vnebovzetje (mak. Golema Bogorodica) in na dan zavetnika samostana sv. Joahima Osogovskega. Avtor opazuje in analizira sodobne obrede in romarske prakse, povezane z lokalnimi verskimi prepričanji in kulturnim spominom na obmejnem območju med Bolgarijo, Severno Makedonijo in Srbijo, in čezmejni verski turizem.

Ključne besede: lokalna religija, meja, identiteta, kulturni spomin, romanje, verski turizem

\section{INTRODUCTION}

The year 2009 was designated as the Year of Faith Tourism by the World Religious Travel Association (WRTA). ${ }^{1}$ This marked the extent to which faith influences phenomena of modern everyday life such as mass tourism and highlighted the fact that religious values and institutions still maintain their strong bond with society. Contextualized by the defragmented life of modern society, individuals are returning to places that used to be (and perhaps continue to be) significant for homogeneous groups, tied together by a greater belief in transcendental values. Modern pilgrims seem to be searching for ways to experience their faith in more than just reading (or singing) holy texts. In the words of the WRTA president, Kevin J. Wright:

Never before has a time been so ripe for the promotion of and participation in Faith Tourism. Although religious travel is the historic forerunner of today's mass tourism, only now is Faith Tourism beginning to make its presence and economic contributions known throughout society and the travel industry in a big way [...]. Faith Tourism is a market that is currently experiencing extraordinary growth on multiple fronts and is poised to continue this trend into 2009 and beyond. ${ }^{2}$

1 More about the WRTA is available at http://worldreligioustravelassociation.blogspot.com.

2 See http://www.prweb.com/releases/2008faithtourism/6religioustravel/prweb1063934.htm. 
Despite the downturn in the economy and the global market in 2008, it was a record year for the two most frequently visited Christian religious pilgrimage destinations: Jordan and Israel. The global tendency toward religious tourism marks the diverse nature of tourism itself and tourists as human contingents, driven by numerous reasons to find their way to religion, motivated by its clearly market or capitalist nature or by the search for social interaction. Easy access to information about "popular" and the "unpopular" religious sites through the internet and social media is now giving people the chance to travel as tourists and/or pilgrims, seeking to reflect on or strengthen their faith and to find a miraculous place that will offer them an alternative to prosaic life.

Here the framework can be maintained for the notion of "faith travel" as "tourism motivated by religious or spiritual reasons or associated with religious heritage sites." ${ }^{3}$ An important preliminary division among the representatives of this activity should be made; namely, into people traveling for religious motives and those simply visiting famous sites that are religious in nature. Thus religious tourism can be divided into two main types: 1) spiritual pilgrimage tourism and 2) religious tourism excursions with a cognitive orientation, involving experiencing religious manifestations to educate oneself about the products they give rise to, such as art, culture, architecture, and traditions.

Within the framework of European ethnology, research on the social and cultural phenomena created by "religion in movement" and its correlation with the ongoing development of the "tourism lifestyle" has been developing rapidly in the past few decades, especially after the fall of the Iron Curtain and the democratization of eastern Europe. The overwhelming transformations in political, economic, and social development in the former communist countries are accompanied by significant changes in the religious life of their societies. The religious restrictions during the communist years were followed by a demonstrative expression of religious feelings, especially in the 1990s, when a number of denominations traditional for the region reappeared in the public sphere. In the past several years, a number of conferences and roundtables dealing with pilgrimage and religious tourism were held by ethnologists and sociologists of religion from Bulgaria and the countries of the former Yugoslavia. Examples include the conference Verovati ili putovati (To Believe or Travel) in Belgrade and the conference Hodočasća, kultna mesta i verski turizam (Pilgrimages, Cultic Places, and Religious Tourism) in Niš. There have been many studies examining the religious landscape in southeastern Europe (Troeva, Hristov, 2017: 1-18).

Scholars note that in the past twenty years the pilgrimage as a religious practice has experienced a global boom (Coleman, Elsner, 1995; Jansen, Notermans, 2012; Taylor, 2012: 210). They emphasize its heterogeneity as an arena for competing religious and secular discourses (Eade, Sallnow, 1991: 2). As early as the 1970s, Victor and Edith Turner defined the pilgrimage as a liminal phenomenon with emphasized rituality (Turner,

3 As perceived and used by the World Tourism Organization (UNWTO) and cited in http://www. multifaiths.com/faith-communities/religious-tourism. 
Turner, 1978) and therapeutic dimensions (Dubish, Winkelman, 2005). Later interpretations examine it as a form of mobility (Coleman, Eade, 2004), as well as an act of moral geography (Taylor, 2012: 211), and the pilgrims themselves are seen as a typical symbol of "religion in movement" (Hervieu-Léger, 1999: 65). The political aspects and relations of pilgrimages (Dubish, 1995; Jansen, Notermans, 2012; Pazos, 2012) and tourism (Badone, Roseman, 2004; Timothy, Olsen, 2006) are also an important perspective of the analysis. The attention of Bulgarian researchers has been drawn to the traditions of the pilgrimage and its modern manifestations (Ivanova, 1995, 2000; Gyurova, 1996; Vŭlchinova, 1999, 2009; Bakalova, 2006; Georgieva, 2006, 2012; Bakalova, Lazarova, 2009; Baeva, 2012; Troeva, 2013; Troeva, Hristov, 2017).

An important distinction should be made here. When the all the phenomena related to the notion of faith are studied by ethnologists, they could be examined on the one hand as a function of the church, of the dominant ideology, or of the government and its politics, but on the other hand they can be viewed as one's intimate feelings, or a question of personal choice. In other words, one ought to make a differentiation between faith and religion, as well as between pilgrimage and religious tourism. The question of the industrialization of pilgrimages or faith tourism as business has been extremely important in the last decade in the context of rapidly developing religious tourism in the Balkans. It is targeted both at people going on pilgrimages to visit a place believed to have miraculous relics, icons, and sacred artifacts (Troeva, 2013: 127) and at tourists, attracted not so much by certain religious feelings as by a desire to see places of national or local significance. All this is a question of the attitude of the relevant institutions: church, state, and local authorities. Nevertheless, the main focus of this research is on another aspect: How and to what extent has the religious tourism in the last two decades influenced a possible identity reshaping process among the population of a border area in the central Balkans - namely, at the triple border between Bulgaria, North Macedonia, and Serbia?

The fieldwork at Osogovo Monastery and St. Gabriel of Lesnovo Monastery, conducted as part of a mutual project between the Bulgarian Academy of Sciences and the Macedonian Academy of Sciences and Art, is just the beginning of an anthropological study that aims to register the special features of the identity construction process under way today in the Balkans and especially in the borderlands between Bulgaria, North Macedonia, and Serbia. Therefore, the main research questions of the future work are as follows: 1) What is the social and cultural meaning of transborder pilgrimage and faith tourism in the "glocal" conditions of the modern Balkan countries from the perspective of their future EU integration? 2) Will the lifestyle of faith tourism become a basis for reconstructing lost cultural proximity between the people of the region between Sofia, Niš, and Skopje (known as Špluk), announced as a prospective Euroregion? 3) Accepting the fact that in the context of transborder mobility the notion of tradition is understood more as people's attitude toward their own cultural past, which is being constructed and employed by every other generations' identity, what will they tell their children and grandchildren about the 
erstwhile "spiritual brothers" and hermit saints from the central Balkans: St. John of Rila, St. Joachim of Osogovo, St. Prohor of Pčinja, and St. Gabriel of Lesnovo?

The initial hypothesis of this article is that in modern times religion in the Balkans suggests an integrative framework for the post-communist societies, whose "new" identities are problematic, and whose religious beliefs are associated with new ethno-national projects, ensuring a feeling of continuity with the pre-communist past (Iveković, 2002: 534).

\section{THE LEGEND}

A legend from the central Balkan area tells the story of four hermit saints that are brothers: St. John of Rila, St. Joachim of Osogovo (or Joachim of Sarandopor), St. Prohor of Pčinja, and St. Gabriel of Lesnovo. Its content varies, with different points of view on whether the four saints were brothers by blood in the Ovče Pole region or by spirit and faith in the Osogovo, Lesnovo, and Kavadarci regions in North Macedonia (cf. Vražinovski, N.d.).

This folklore narrative has its prototype in the extensive biography of St. Joachim of Osogovo, Žitie i žizn prepodobnago otsa nashego Joakima Sarandoporskago (The Biography and Life of Our Father Joachim of Sarandopor), known from several fifteenth-century copies and from publications in contemporary Bulgarian and Macedonian, by the ethnographer Dimitar Marinov in 1900 and Vera Antić in 1977, respectively. This is the original text of the biographical narration concerning the legend published by the historian Jordan Ivanov:

Brothers in fasting and prayers, torturing their flesh, which came out to the world to rot, secluded themselves in the woods and deserts, living on prayers and tears. Later they were followed by successors, accepting a life like this, of our true newly devoted fathers and hermits, heavenly people and earthly angels, followers of Christ, John and Prohor, together with Gabriel and the reverend father of ours, Joachim, all four of them forming a God-chosen association as hardworking followers of Christ. ${ }^{4}$ (Ivanov, 1931: 405-407)

In his Istoria Slavianobolgarskaya (Slavic Bulgarian History, circa 1762), Paisius of Hilendar from Bansko (Bulgaria), a monk at Mount Athos, called St. John of Rila the leader of the other three saints, defining him as their spiritual father:

A lot is being said and written in human doxologies about our four reverend saints,

Gabriel, Prohor, Joachim, and Joanikie, that they were students of the reverend

4 From here onward, all the English translations from Macedonian or Bulgarian are by Mina Hristova, to whom thanks are expressed. 
father John. He brought them and enlightened them into the paths of the holy life and the rules of the monks. [...]

And so through the prayers of father John his four holy students shone like stars. They started the first monastic order in Bulgaria, and many monasteries were built during their time in Bulgaria [...]

Thus the holy father from Rila became the forefather of the monks in Bulgaria.

[...] (Ivanov, 1906: 84)

Surviving through the ages, this folk legend is still functioning among the population of this region, telling the story about the four spiritual brothers, who lived their lives in isolation and hermitage in four different places, which later on became sacred topoi for the central Balkan area (the border area between North Macedonia, Bulgaria, and Serbia). The narrative was recorded many times in different variations, but the most detailed version was published by the Macedonian ethnologist Tanas Vražinovski in 1988 in Kriva Palanka (Vražinovski, 1998: 303, 307-309); this was also the legend that was narrated by the locals on the patron saint's day of Osogovo Monastery on August 29, 2020.

The legend is visualized in various combinations of the images of the four hermit saints, which can be seen on icons and frescoes from the nineteenth century and first half of the twentieth century in a number of churches and monasteries in the central Balkans, including the border areas of the three countries. At both Osogovo Monastery and St. Nicholas's Church in Kratovo, the icons of St. Joachim of Osogovo and St. John of Rila are linked: in the first case on the iconostasis, and in the second on both sides of the church's entrance. What is probably the most popular image of the four saints can still be seen on an icon from the nineteenth century in the left corner of the iconostasis in the church in Kratovo (Figure 1). The most recent image of this type is at Dormition Church (known as Čepreganov's church) in the cemetery in Novo Selo, close to Štip in North Macedonia, where it was placed above the iconostasis.

Despite the new political frontiers established after the Balkan wars and especially after World War I, until the middle of the twentieth century the spiritual unity of the four saints from the central Balkans and the folk vision of their "brotherhood" were not problematized. Nevertheless, after the Second World War, the memory of the holiness of the spiritual protectors of the valley between the Struma River and Mount Osogovo slowly faded from collective consciousness. This fact is partially a result of the official atheist propaganda of the early communist decades, which was more aggressive in Bulgaria than in the former Yugoslavia, and partially a result of the ideological differences on both sides of one of the most strictly guarded borders after 1948: the Macedonian-Bulgarian border.

The situation changed at the beginning of the 1990s after the fall of the Berlin Wall: in Bulgaria, the past twenty-five years of transition toward democratization transformed the post-communist religious revival into an aspect of the global rise of religiosity (more in Troeva, Hristov 2017: 1-18), whereas in North Macedonia the revival of Orthodoxy and the 


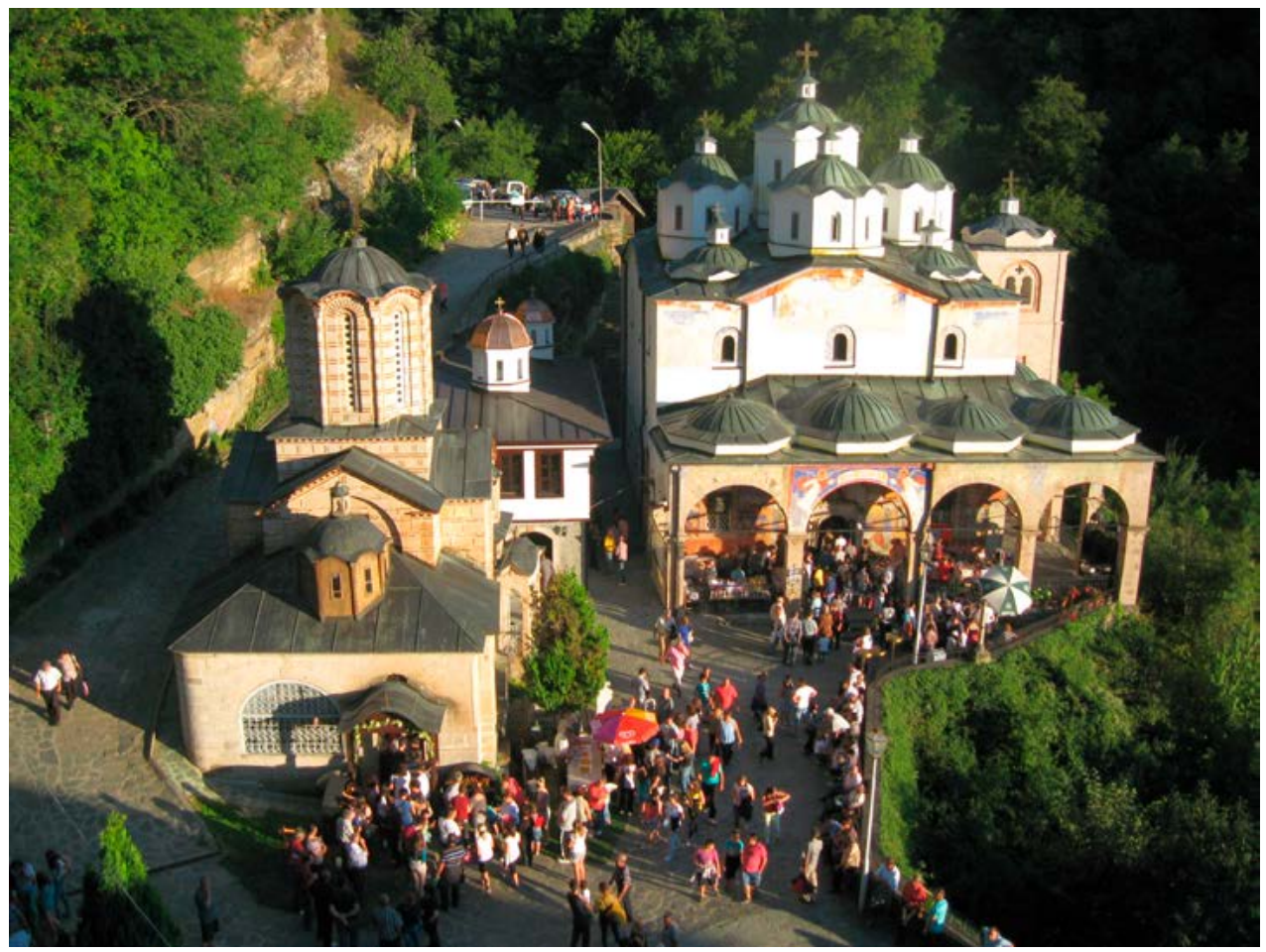

Figure 1. Temple holiday of the Osogovo, August 29, 2014 (photo by Petko Hristov).

independence of the Macedonian Orthodox Church became a significant part of the new national ideological construction of the independent Macedonian state. In this situation, St. John of Rila, announced as the "spiritual protector of the Bulgarian nation" during the Third Bulgarian Kingdom in the early twentieth century, is becoming inconvenient and is consequently being omitted from the official list of "Macedonian saints" (Georgievski, 1997: 8), and he is therefore losing his place among the "saints of Macedonian origin" in popular consciousness (Vražinovski, 2011: 25). According to Vražinovski, the Macedonian national tradition "loses the traces" of the saint after he parted with his brothers and settled at Mount Rila, and this would therefore explain his absence from popular oral tradition. The inclusion of St. Prohor of Pčinja Monastery — where "the first session of the Anti-Fascist Assembly for the National Liberation of Macedonia was held and the Socialist Republic of Macedonia was announced as a nation state in federal Yugoslavia" on August 2, 1944_in Serbian territory in the 1950s is also appraised as "incorrect" (Georgievski, 1997: 119). Thus, two of the four saintly brothers from the region are selectively removed from the tradition, after becoming an eponym of other national cultures that are often evaluated as contradictory and assimilative. Nevertheless, the ambivalent image of St. Prohor of Pčinja, known as a saint of Macedonian origin, and the perception of the monastery as a milestone of the political creation of the Macedonian nation-state, still retain his presence 
in the official narrative of the state and the church, as well as the unofficial one of the folk culture, contrary to case of St. John of Rila.

In addition, in the visualization of the national pantheon of the Macedonian nation, the Skopje 2014 project, the image of St. John of Rila is missing among the statues of the other hermit saints from Mount Osogovo: St. Prohor of Pčinja, St. Gabriel of Lesnovo, and St. Joachim of Osogovo. In the new pieces of art at Osogovo Monastery-and precisely in one of the most visited areas, the dining area of the old konak ${ }^{5}$ - the absence of St. John of Rila is evident once again.

Nevertheless, this ideological "exclusion" does not change the modern social practice of transborder religious tourism between Bulgaria and North Macedonia. During the last few years, the flow of Bulgarian tourists has constantly been rising and is becoming more organized.

\section{RELIGIOUS TOURISM}

The proximity of the region to national borders suggests easy access to the region from the Bulgarian side of the border and thus leads to the presumption that the paths of the tourism infrastructure can vary, ensuring a diverse environment for tourists, with a wide range of places to visit and activities to engage in (Maud, 2011: 16). This fact also allows cross-border tourists to choose different means of transportation: by car or arranged buses. Both of these groups can easily be seen in the surroundings of Osogovo Monastery, as well as in the town of Kriva Palanka. On August 29 the researcher often encountered Bulgarian families, who came unorganized during the second half of the day (taking into account that the holiday was on Friday: this was an official holiday and thus a non-workday in North Macedonia, but it was a normal workday for Bulgaria). Most of them came from the town of Kyustendil, which is located about twenty kilometers from the border.

Kriva Palanka is a popular destination among the Bulgarian urban population, mostly known for its high-quality products, which can be bought there for reasonable prices. Based on observations in Kyustendil, most people prefer to spend some of their weekends in Kriva Palanka, enjoying some of the most popular restaurants in its surroundings (Vodenica 3 and Etnoselo), which are known for their traditional and tasty cuisine. All this is done alongside shopping for products (sirene and kashkaval cheese, etc.) for their households, widely perceived as being of higher quality than the goods in Bulgaria. These economic motives are adding some additional details to the character of cross-border tourism in the region.

5 The konak is the main building of a monastery complex, providing pilgrims visiting the sacred place with rooms. These are usually constructed to reflect monastery life and therefore almost always contain only a bed. The building has common places for shared preparation of meals, as well as common rooms where the devotees eat together. 
Nevertheless, the people in Kyustendil do know about the monastery and choose it as a destination for one-day trips, planned as an "escape" from the city and the obligations of everyday life. A brief overview of the Facebook profile of the monastery (as a place) indicates the approximate profile of the visitors, coming from all parts of North Macedonia and Bulgaria (primarily from Kyustendil, Dupnica, and Sofia).

In this context, with the rise of the information flow through the internet, tourists seeking new places have easy access to various information providers: blogs, ${ }^{6}$ tourist websites, information websites, forums, and websites for video sharing, all distributing a variety of insights and knowhow about the tourist experience in the chosen region. All this is usually accompanied by various informal information networks, sustained by family, friends, relatives, and so on, combined with the formalized informative material provided by the tourist industry.

Because this variety of mechanisms and motives sustaining cross-border tourism in the region is evident in the case of the Macedonian-Bulgarian border, I cannot simply characterize this diverse and multidimensional process of a border-crossing population as "religious tourism." The internal motives of visitors to holy places may vary from their expectation to experience an area believed to be connected with a holy man, which contributed to the creation of strong bonds with God, or a man believed to be miraculous, to curiosity and hesitation to experience a different or the same tradition, which is located geographically close but constituted as different by the existence of borders.

In addition to the aforementioned strategies, here I turn attention to the fact that a number of Bulgarian tour operators ${ }^{7}$ offer year-round, usually one-day trips to both monasteries: St. Gabriel of Lesnovo and St. Joachim of Osogovo. Most of the agencies offer relatively low prices, given the competitiveness of the market for one-day trips in Bulgaria and especially the number of tours offered for Osogovo Monastery. These tours are usually accompanied by what is advertised as an "ethno-lunch" at one of the well-known ethnorestaurant complexes, featuring traditional cuisine and drinks. Some of the tourist groups that I met late in the afternoon on August 30 stated that they had crossed the border later than expected and had decided to have lunch first, before visiting the monastery. Looking further through the excursion offers, it is apparent that some of the brief historical references provided together with the day-plan of the excursion represent an ethnocentric point of view ("a well-known Bulgarian saint") ${ }^{8}$ with regard to the ethnic or national origin of the monastery's patron saint. Others refer to St. Joachim as a "local saint," "one of the first disciples of St. John of Rila," or a "legendary saint." The image created of the saint as Bulgarian may be understood as another motivation for Bulgarian tourists, who are willing to see something that is believed to be theirs.

6 For example, http://staronagoricane.blogspot.com/2010/07/blog-post_31.html; http://poklonnik. mitov.org/? $\mathrm{p}=414$.

7 For example, http://www.beckreisen.bg/excursion_makedonia/view.html?oid=70883; http://www. loyal-travel.com/ekskurzii/osogovski-manastir-s-etno-obiad-2950.html.

8 http://www.globetravel-bg.com/offer/cat_420/offer_2422.html. 
On the other hand, the website of the Macedonian Orthodox Church shows a different point of view, presenting the saint as the Church's representative, responsible for sustaining and maintaining the faithfulness of the people from the region and the nation as a whole, in response to the numerous "attacks on the Macedonian people and their faith." It is also said that the celebration of St. Joachim of Osogovo Day turns the monastery into a center with spiritual dimensions transcending the limits of the continent. ${ }^{9}$

The official points of view, transmitted through the internet, provide both opposing nation-state narratives aimed toward the border area: the one of the Bulgarian side, claiming its "ownership" on the saint, and the one of Macedonia, creating an image of the saint and his monastery as a sacred place of world-ranked significance. All this is supported by the fact that the region is both included in the national space of North Macedonia and is nonetheless geographically distant from the dominant symbol of the nation-state, represented in the capital city of Skopje, thus obtaining the status of both as a product of its distance from the political center and the ethnic makeup of the region.

\section{THE PATRON SAINT'S DAY AT OSOGOVO MONASTERY}

On the patron saint's day of Osogovo Monastery (August 29) ${ }^{10}$ there were mainly families from Kyustendil, as well as organized buses from across the country. For example, late on Friday afternoon I met tourists (mainly women, middle-aged and older) from Svoge, who came with an organized bus. Their first question, realizing they were meeting Bulgarians was: "Is there still holy water?" This was a clear statement for the purposes of the visit. According to the monastery's vicar, several buses with Bulgarian tourists come every Saturday and Sunday during the entire year.

Of course, Macedonian tourists dominated. Despite people coming from the villages surrounding Kriva Palanka, Kratovo, and Kumanovo, many tourists came from Skopje that day, as well as an organized tour bus from Ohrid. From August 27 onward, many pilgrims came to the monastery to spend the remaining days of the two major Orthodox holidays there (the Dormition of the Mother of God on August 28, and the day of the patron saint, Joachim of Osogovo, on August 29). The rooms of the konak were booked months before these dates, and therefore one could occasionally see devotees sleeping on the wooden balcony of the building, almost "under the stars," enjoying the breathtaking view of the monastery. Every day, with the approaching of the dates, more people would come, until there was almost no place on the balcony of the konak to accommodate them all.

More at http://www.mpc.org.mk/mpc/osogovskimanastir.asp.

10 I carried out fieldwork in the summer of 2014 and 2015 with Mina Hristova. An earlier coauthored version of this article was published in 2014 in Etnolog 15: 45-61. 
An important fact, evident for every visitor during the holidays, was the communal spirit, which was clearly seen. During the two days people from all over Macedonia would sit together, sharing a table at lunch, or preparing their meals in the common kitchen. On the 28th and 29th, people from Kriva Palanka, marked as volunteers, could be spotted on the grounds of the monastery: some were taking care of the animals, which were sacrificed as kurban, ${ }^{11}$ some were preparing the common meal for all the visitors coming for the celebrations, and some were taking care of accommodation for the guests. When asked why he was doing volunteer work at the monastery, a sixty-year-old man answered: "I have been coming here every year for a long time. We are so sinful that the least thing I can do is come here every year and help the monastery on this sacred day."

Openly contested by the visitors or not, a number of motives for the pilgrims to come to Mount Osogovo could be observed during these days. Some people enjoyed the social aspect of the event: mothers were searching for wives for their sons, looking around and taking photos of the young women, animatedly discussing how beautiful or intelligent they looked. Some were enjoying sharing a table with strangers, discussing a variety of topics - from the weather to economics and politics. Some were enjoying the Roma ensembles that came there (Figure 2), expecting to earn their living for some months ahead. Some came to take a walk in the monastery's beautiful surroundings and see the flea market, filled with numerous products, representing an incredible amalgam between modernity and Christianity. The diverse mass of tourists, visitors, and pilgrims created a community outside of the everyday routine, relieving them from the obligations of their usual social roles, or their nationality and personalities, and gathering them, despite all their differences, in a society bound to its faith, traditions, and beliefs. The social role of the event was substantial for all of them, granting them an escape from their everyday lives.

The monastery's administration strove to respond to the expectations of its guests. Special stalls selling souvenirs and offerings were set up on both sides of the church's entry. A Macedonian colleague summarized this as follows: "Unlike St. Gabriel of Lesnovo Monastery, Osogovo Monastery had turned into a tourist place already; but Rila Monastery is far ahead regarding this." Religious pilgrimage has its history of being an economic generator, sometimes even anchoring entire local economies, and so in many cases the economic benefits are seen to outweigh the negative impacts (Timothy, 2006: 10-12). Therefore, at Osogovo Monastery the priests accepted these demands imposed by the new reality; they even went around the tables talking with the sellers, and they were watching over the entire process.

On the patron saint's day of the monastery, the number of visitors rose compared to the previous holiday, the Dormition of the Mother of God (Mac. Golema Bogoroditsa,

11 Kurban is a traditional sacrificial meal, common among Orthodox people and Muslims at traditional holiday celebrations in the Balkans (cf. Sikimić, Hristov, 2007). On August 28, fifteen lambs were given by devotees for sacrifice, often accompanied by prayers for the health and prosperity of the families of those donating the animal. 


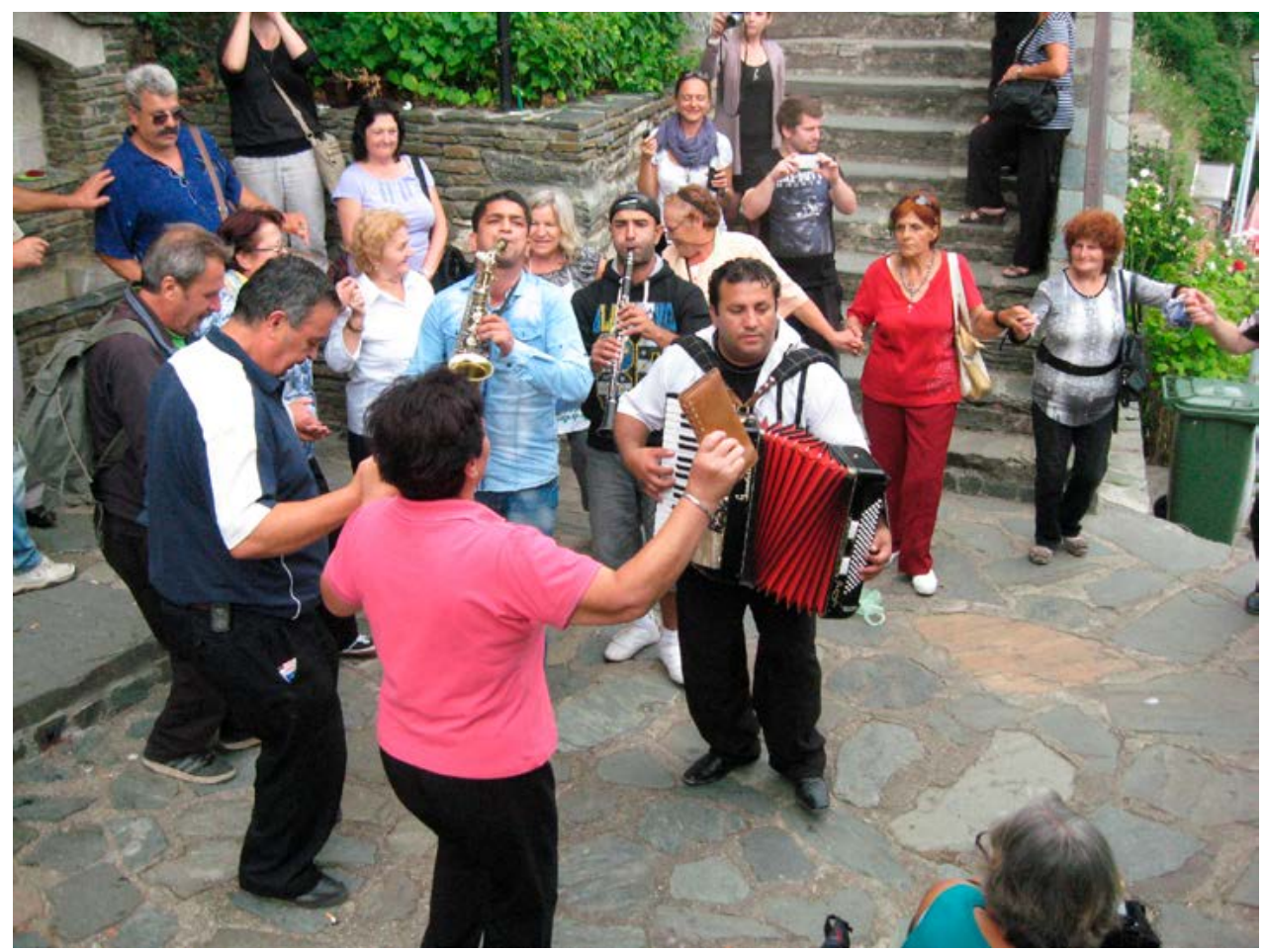

Figure 2. Gypsy orchestra and dance in the yard of the monastery on the feast of St. Joakim Osogovski, August 29, 2014 (photo by Petko Hristov).

August 28). According to a respondent: "Today [August 28] it is mainly people from the villages in the area coming in the monastery, but tomorrow people will be coming from all over the country: Skopje, Ohrid, and so on. Every year we have tourists from Bulgaria, from Kyustendil."

In front of the church's doors, a certain division among the crowd of tourists was visible. The older ones were gathering around the stall with the offerings, bottles of oil, and clothes given to the church by devotees, which were then offered for sale, and the money raised was given to the church. On the opposite side at a large stall long lines of icons of St. Joachim of Osogovo, Mary, and other saints were arranged, next to small bottles of blessed oil, bracelets with colorful glass arranged in cross shapes, and other jewelry with religious symbolism. All these attracted the younger visitors to the monastery, who seemed fascinated by the variety of items on display. The amalgam between modern accessories and Christian motifs was evidently attractive to the younger female tourists, who found also more entertainment at the flea market in the meadow above the monastery. Here, at these doors, a clash of realities can be observed: people striving to anchor their own memories through a material item (a souvenir) and loading it with meaning and/or memories, versus seekers of faith, believers, and those searching for "the truth." 
The dichotomy between the pilgrims and tourists was revealed at the church doors. In the context of the sacred space, these two groups became structurally similar, being forms of one another and sometimes "even when the role(s) of tourist and pilgrim are combined, they are necessarily different, but form a continuum of inseparable elements" (Grabum, 1983: 16). Often a person would combine the two categories mentioned above. This was evident on August 29, when a number of families, probably motivated by reasons often attached to the tourist profile (i.e., relaxation, pleasure, curiosity, and desire for shared family time on their free day) came to the monastery. After first buying souvenirs from the stalls, some mothers would stand at the church door and would teach their children how to enter the holy place and how to act inside. Young children in their fathers' arms could be seen lighting candles under their parents' careful guidance.

In this commercialized area, the liminal place (the church's door, separating the church itself from the monastery yard) divided the world that is closer to everyday life, with its typical social behavior (chatting, laughing among the monastery guests) and economic relations (bargains, choices, desire for materiality), from the one inside: sacred, close to God and the saints, which people enter to strengthen their bonds with them, to beseech them, and to pray for release from the heavy burden of everything beyond human understanding.

An important thing to be noted here is the fact that in the border region there is cross-border tourism to both sides of the border. The respondents from Kriva Palanka and Kratovo stated that they had visited Rila Monastery (with its patron St. John of Rila) in Bulgaria at least once, and some even more often, including for religious reasons. This is corroborated by the fact that the number of the organized excursions from this region to Rila Monastery has constantly been increasing over the past several years. An interesting fact is that other monasteries in Bulgaria that are of national significance are not as popular among people from northeastern North Macedonia.

\section{CONCLUSIONS}

The contrast between the tourists and pilgrims at Osogovo Monastery on the borderland of contested identities, separated between the two nation-states of Bulgaria and North Macedonia, creates a specific space loaded with numerous meanings. Osogovo Monastery, like every other sacred place, was built and sustained until now by religious people and pilgrims to be a reflection of the constant striving for interaction with sacred powers, whereas the tourism practices established by the visitors and driven not only by the holiness of the place, but also by the need for socialization, relaxation, or curiosity, are creating "parallel geographies of both the sacred and the touristic" (Timothy, 2006: 25). Moreover, the meaningful load of these overlapping realities is meeting at their core, sustained by the living narratives of a shared spiritual brotherhood of the people on the three sides of the border, creating and consolidating bonds that connect and reconnect them to the place. 
Contested or not, the legend of the four hermit brothers-St. John of Rila, St. Joachim of Osogovo, St. Gabriel of Lesnovo, and St. Prohor of Pčinja-is still motivating pilgrims and tourists to visit the sacred landmarks on the border in search for the truth, to examine whether there is otherness on the other side of the border, and to explore their own limits between "us" and "them." Nevertheless, these tourist sites convey narratives that articulate coherent identities based on a legend of a once-shared spiritual past.

All this creates a basis to suggest that in the context of pan-European mobility, which North Macedonia and Serbia will be soon included in, transborder religious tourism in the central Balkans will continue and become even more frequent. It is also hoped that the revival of pilgrimages and religious tourism will lead to overcoming the imposed ideological restrictions, and that it will revitalize the Orthodox Christian unity of the population in these regions, which existed long before the establishment of political borders in the first half of the twentieth century.

\section{REFERENCES}

Badone, Ellen, and Sharon R. Roseman, eds. 2004. Intersecting Journeys: The Anthropology of Pilgrimage and Tourism. Urbana, Chicago: University of Illinois Press.

Baeva, Vichra. 2012. Meždu enorijskija život, poklonničestvoto i turizma: ruskata cărkva Sv. Nikolaj Mirlikijski Čudotvorec v Sofija. Bălgarska etnologija 2012 (1-2): 19-36.

Bakalova, Elka. 2006. V tărsene na čudoto: poklonničestvo pri čudotvorni ikoni. Istoričeski aspekti i săvremenni praktiki. In Ljuben Praškov - restavrator i izkustvoved, ed. M. Praškova, 40-55. Sofija: Universitetsko izdatelstvo Sv. Kliment Ohridski.

Bakalova, Elka, and Anna Lazarova. 2009. Tradicijata na poklonničestvoto - srednovekovni izvori i săvremenni praktiki. In Narodni kulturi i balkanski tereni, ed. Mila Santova, 103-117. Sofija: Akad. izdatelstvo Prof. M. Drinov.

Coleman, Simon, and John Eade. 2004. Introduction: Reframing Pilgrimage. In Reframing Pilgrimage: Cultures in Motion, eds. Simon Coleman and John Eade, 1-25. London: Routledge. DOI: https:// doi.org/10.4324/9780203643693.

Coleman, Simon, and John Elsner. 1995. Pilgrimages: Past and Present in the World Religions. Cambridge: Harvard University Press.

Dubish, Jill. 1995. In a Different Place: Pilgrimage, Gender, and Politics at e Greek Island Shrine. Princeton: Princeton University Press. DOI: https://doi.org/10.1515/9781400884414.

Dubish, Jill, and Michael Winkelman, eds. 2005. Pilgrimage and Healing. Tucson: University of Arizona Press.

Eade, John, and Michael J. Sallnow. 1991. Introduction. In Contesting the Sacred: The Anthropology of Christian Pilgrimage, eds. John Eade and Michael J. Sallnow, 1-29. London: Routledge.

Georgieva, Albena. 2006. Poklonničestvoto - pătuvane otvăd različieto. In Bregăt - moreto - Evropa, eds. Mila Santova, Iva Stanoeva and Miglena Ivanova, 165-172. Sofija: Akad. izdatelstvo Prof. M. Drinov.

Georgieva, Albena. 2012. Folklorni izmerenija na hristijanstvoto. Sofija.

Georgievski, Mihajlo. 1997. Makedonski svetci. Skopje: Kultura. 
Gjurova, S. 1996. Poklonničestvo i poklonničeska literatura. Sofija: Vreme.

Graburn, Nelson H. H. 1983. The Anthropology of Tourism. Annals of Tourism Research 1983 (1): 9-34. DOI: https://doi.org/10.1016/0160-7383(83)90113-5.

Hervieu-Léger, Daniele. 1999. Le Pèlerin et le Converti, la Religion en Mouvement. Paris: Flammarion.

Ivanov, Jordan. 1906. Severna Makedonija.

Ivanov, Jordan. 1931. Bălgarski starini iz Makedonija. Sofija.

Ivanova, Evgenia. 1995. Utilitarnata sakralnost - otkrivane na ponosimostta. Bălgarskifolklor (1-2): 102-117.

Ivanova, Evgenia, ed. 2000. Krăstova gora - poleznoto čudo. Sofija: Institut za iztočno-evropejska humanitaristika.

Iveković, Ivan. 2002. Nationalism and the Political Use and Abuse of Religion: The Politicization of Orthodoxy, Catholicism and Islam in Yugoslav Successor States. Social Compass 49 (4): 523-536. DOI: https://doi.org/10.1177/0037768602049004004.

Jansen, Willy, and Catrien Notermans, eds. 2012. Gender, Nation, and Religion in European Pilgrimage. Surrey: Ashgate.

Maud, Jovan. 2011. Sacred Tourism and the State: Paradoxes of Cross-Border Religious Patronage in Southern Thailand. MMG Working Papers. Göttingen: Max-Plank-Gesellschaft.

Mihajlovski, Jordan. 2008. Manastir Sveti Joakim Osogovski. Skopje.

Pazos, Anton M., ed. 2012. Pilgrims and Politics: Rediscovering the Power of the Pilgrimage. Aldershot: Ashgate.

Radisavljevic Ciparizovic, D., ed. 2010. Pilgrimages. Niš: Cult Places and Religious Tourism.

Sikimić, Biljana, and Petko Hristov, eds. 2007. Kurban in the Balkans. Belgrade: Institute for Balkan Studies.

Taylor, Lawrence. 2012. Epilogue: Pilgrimage, Moral Geography and Contemporary Religion in the West. In Gender, Nation, and Religion in European Pilgrimage, eds. Willy Jansen and Catrien Notermans, 209-220. Surrey: Ashgate.

Timothy, Dallen J., and Daniel H. Olsen, eds. 2006. Tourism, Religion \& Spiritual Journeys. London, New York: Routledge. DOI: https://doi.org/10.4324/9780203001073.

Troeva, Evgenia. 2013. Geografija na sakralnata mobilnost: Relikvi, mošti i poklonničestvo v načaloto na XXI vek. In Etnografski problemi na narodnata kultura, t. 10, ed. Anatol Ančev, 127-180. Sofija: Akad. izdatelstvo Prof. M. Drinov.

Troeva, Evgenia, and Petko Hristov. 2017. Sacred Geography of the Post-Socialist Balkans: Transformations of Religious Landscape and Pilgrimage. Southeastern Europe. L'Europe du Sud-Est 41 (1): 1-18. DOI: https://doi.org/10.1163/18763332-04101001.

Turner, Victor, and Edith Turner. 1978. Image and Pilgrimage in Christian Culture: Anthropological Perspectives. New York: Columbia University Press.

Vălčinova, Galina. 1999. Znepolski pohvali: Lokalna religija i identičnost v Zapadna Bălgarija. Sofija.

Vălčinova, Galina. 2009. „Rodopskijat Jerusalim” vs. „Rodopskata Meka”: Sveti mesta, granici i nacionalna politika, XIX - XXI vek. Anamnesis 4 (1): 60-131.

Vražinovski, Tanas. N.d. Svetite Ivan Rilski, Joakim Osogovski, Gavril Lesnovski i Prohor Pčinski vo Makedonskata narodna tradicija. Skopje: Institut za staroslovenska kultura. http://www.ongal.net/ editions2/1100Years_st.Ivan_Rilski00_pdf/7_1100Years_Vrazhinovski00_web.pdf.

Vražinovski, Tanas, ed. 1998. Narodna mitologija na Makedoncite. Kn. II. Etnografski i folklorni materijali. Skopje, Prilep.

Vražinovski, Tanas. 2011. Manastirite i crkvite vo narodnata tradicija. Skopje: Matica makedonska. 


\section{SVETI KRAJI IN KULTURNI SPOMIN NA TROMEJI: REVITALIZACIJA ČAŠČENJA SVETNIKOV PUŠČAVNIKOV V SAMOSTANU OSOGOVO}

Vrazpravi so predstavljeni rezultati terenskega dela v samostanu Osogovo (Severna Makedonija), ki ga pri skupnem raziskovalnem projektu izvajata Makedonska akademija znanosti in umetnosti in Bolgarska akademija znanosti. Terensko delo je potekalo ob velikem krščanskem pravoslavnem prazniku Vnebovzetje (mak. Golema Bogorodica) in na dan zavetnika samostana sv. Joahima Osogovskega. Avtor v razpravi dokumentira in analizira sodobne obrede in prakse romarjev, povezane z lokalnimi verskimi prepričanji in kulturnim spominom na obmejnem območju med Bolgarijo, Severno Makedonijo in Srbijo, in tematizira čezmejni verski turizem. Še vedno je živa stara legenda o duhovni bratovšcini štirih svetnikov - sv. Joakim Osogovski in sv. Gabrijel Lesnovski (danes v Severni Makedoniji), sv. Janez Rilski (danes v Bolgariji) in sv. Prohor Pčinjski (danes $v$ Srbiji). Legenda še vedno spodbuja romarje in turiste k obisku in iskanju resnice o tem, ali obstaja kaj na drugi strani ter o meji med "nami in "njimi«.

Vse to krepi domnevo, da se bo v okviru vseevropske mobilnosti, $v$ katero bosta kmalu vključeni Severna Makedonija in Srbija, čezmejni verski turizem na osrednjem Balkanu nadaljeval in postal še pogostejši; pri tem je upanje, da bo oživitev romanja in verskega turizma pripeljala do premagovanja starih ideoloških, a tudi nacionalnih omejitev.

Prof. Dr. Petko Hristov, IEFSEM, Bulgarian Academy of Sciences, petko.hristov@iefem.bas.bg 